This item was submitted to Loughborough's Research Repository by the author.

Items in Figshare are protected by copyright, with all rights reserved, unless otherwise indicated.

\title{
Parental responsibility for paid employment and social reproduction: children's experiences in middle class and working class households in England
}

\section{PLEASE CITE THE PUBLISHED VERSION}

http://dx.doi.org/10.1177/0308518X15597145

\section{PUBLISHER}

(C) Sage; Pion

\section{VERSION}

AM (Accepted Manuscript)

\section{PUBLISHER STATEMENT}

This work is made available according to the conditions of the Creative Commons Attribution-NonCommercialNoDerivatives 4.0 International (CC BY-NC-ND 4.0) licence. Full details of this licence are available at: https://creativecommons.org/licenses/by-nc-nd/4.0/

\section{LICENCE}

CC BY-NC-ND 4.0

\section{REPOSITORY RECORD}

Pimlott-Wilson, Helena. 2019. "Parental Responsibility for Paid Employment and Social Reproduction: Children's Experiences in Middle Class and Working Class Households in England". figshare. https://hdl.handle.net/2134/18008. 


\title{
Parental responsibility for paid employment and social reproduction: children's experiences in middle class and working class households in England
}

\begin{abstract}
Over the last forty years, the labour market has undergone considerable change in the shift from an industrial to post-industrial economy. Profound economic, social and political developments have resulted in the feminisation of the labour force. Employment for parents, and increasingly mothers, is positioned by government policy as a remedy to child poverty at a time when individual responsibility for financial provision intensifies under austerity measures. Geographers have explored the unequal burdens of care borne by women and the gendered moral rationalities which shape labour market attachment from the perspective of adults. This paper shifts this focus to take account of children's understandings of the gendered responsibilities of parents in middle and working class families in relation to employment and social reproduction. Firstly, it considers the persistence of the male breadwinning role in middle class households, resulting in mothers’ paid work being viewed as supplementary by children. Secondly, the paper explores how children understand labour market insecurity for working class fathers and how this impacts upon their mothers, compelling women into employment to bolster the family income. Thirdly, the paper gives consideration to the experiences of those children who live with the everyday reality of low-paid, insecure parental employment, as the negative effects of insecure work permeate the family. In conclusion, the paper highlights the importance of considering children's perceptions of gendered parenting roles both in the here and now, but also as young people look towards their own family and labour market futures.
\end{abstract}

Keywords: children; social class; employment; gender; austerity; geography 


\section{Introduction}

Social, economic and political changes of the last four decades have shifted the organisation of paid work and social reproduction. Shifts within the economy have resulted in a segmented occupational landscape where professional and managerial occupations are characterised by relative stability in contrast to service sector and manual work, typified by insecurity, low pay and recurrent unemployment (Atkinson 2010, 2013). Research within employment geographies has sought to connect studies of this paid work to spaces beyond the confines of the workplace in order "to see workers as parents, partners, consumers, activists and much more besides” (Stenning 2008: 11). These debates have been predominantly adultist, but a handful of studies have begun to explore the profound effects parental employment and unemployment can have for, and on, children in the Global North (cf. Harden et al 2013; MacLean et al 2010; Ridge 2009). The paper develops these emerging debates about children's experiences of parental (un/non)employment by focusing upon the ways in which children perceive parents' gendered roles in the context of different material resources.

The paper makes three contributions to knowledge about parental employment. First, it redresses an adultist imbalance within studies of parents' gendered roles to include the voices of children. Second, the paper examines how children perceive mothers' and fathers' gendered responsibilities for being productive workers in the labour market and how this is reconciled with social reproduction in the home. The paper traces the relative salience of male breadwinning for middle class children and the destabilising effect of labour market insecurity for the gendered role of working class fathers. Children align mothers' paid work with care, rationalising this in terms of lifestyle choices in middle class households and economic necessity in working class families. Third, the paper explores how economic insecurity affects whole families 
rather than individual workers. Specifically, the paper uncovers the implications of mothers churning through poor quality work for the younger members of households. The ability to engage in paid work on an equal footing is central to feminist calls for women's liberation. Concurrently, neoliberal government rhetoric promotes maternal employment as a route out of poverty in a policy context that is underpinned by the notion of gender-equal adult workers. Although some children agree that their mothers' employment increases distance from food scarcity, children understandings of employment at the lower end of the occupational hierarchy draws attention to the need to consider the quality of employment available to mothers and the limitations on their labour market choices. The insecure labour market positions available to working class mothers means that a sense of powerlessness over employment trajectories is shared with children.

The paper begins by outlining labour market and social change of the past forty years which has altered the occupational landscape, whilst neoliberal restructuring has transferred the burden of care to the 'natural' level of the home where women retain responsibility. The subsequent section introduces the qualitative empirical work with children aged five to nine years old in England on which the paper is based. The central sections of the paper explore how for the children of employed mothers, paid work is bound up with caring for the family. Despite employment being a central component of care for these children, their experiences are bifurcated along class lines, as the higher incomes associated with professional and managerial employment insulate against adversity whilst in working class families, employment instability and the realities of low-paid work are an everyday reality for children. In conclusion, the paper emphasises the implications which government policy and labour market security and insecurity can have for individual workers, but also their family. 


\section{Gender in labour markets, government policy, and austerity}

The past four decades have seen a considerable restructuring of the global labour market. The UK manufacturing sector has experienced a significant reduction in operations, resulting in the loss of skilled working class jobs in industry (MacLeavy 2011a). Concurrently, the service sector has experienced expansion, dominating the UK labour market and is a key driver of economic growth (Allen 2014). Although the service industry has expanded, positions in this sector are increasingly characterised by instability, fluctuating working hours and capricious contracts; a profound departure from 'male' breadwinning occupations which had once supported a family. Shifts within the economic landscape have been accompanied by social changes, such as increasing numbers of women with dependent children in the workforce (Perrons 2003). Between 1971 and 2013, the number of women aged 16-64 in employment had increased from 53\% to $67 \%$ whereas for men, employment had fallen from $92 \%$ to $76 \%$ over the same time period (Office for National Statistics 2013). Policies such as The Equal Pay and Sex Discrimination Acts of the 1970s can be perceived to strengthen the place of women within the labour force. More recent changes to lone parent income support and increases in the state pension age have compelled women, to different degrees, to participate in the labour force (MacLeavy 2011a).

Economic, social and political changes have established women’s waged-labour as increasingly central to household survival at a time when inequalities in the workplace remain alongside an unequal division of care and domestic responsibilities in the home (Roberts 2013; Smith et al 2011). Although more women have entered the labour market, there has been a divergence of experience. On the one hand, those 
women possessing higher educational qualifications gain jobs characterised by relative security, yet others without such institutionalised cultural capital suffer insecure and low-paid work. Moreover, despite advances made by women in education and the UK labour market, over the age of 22, men consistently have a higher employment rate than women and work in professional occupations associated with higher levels of pay (Office for National Statistics 2013).

These social and economic changes have been accompanied by a shift in the policy landscape where subsequent governments have adopted neoliberal workfare agendas in an attempt to respond to rising welfare bills. Workfare policies have moved away from state support for welfare to emphasising individual accountability for financial provision (Lewis and Campbell 2007; MacLeavy 2011b). Success (or failure) in the labour market is individualised as opportunities are presented as equally accessible to all, with the rational, responsible citizen-worker portrayed as engaging in paid work, providing for the financial needs of their family and being rewarded with the rights bestowed on those who 'contribute'. Employment opportunities, however, remain strongly aligned with traditional layers of stratification including class, gender, age and ethnicity (Atkinson 2013), which in turn condition life chances. Against a backdrop of economic downturn, those who do not conform to the active citizen-worker vision run the risk of being construed by government rhetoric as at risk of social exclusion and poverty despite the increased vulnerability of workers at the lower-end of the occupation hierarchy to employment instability (Ward et al 2007). Moreover, the gender-blind framing of all adults as potential workers overlooks the moral dilemmas parents face in combining employment and childrearing within dominant societal constructions of their roles, particularly in relation to mothers' ethic of care (Perrons et al 2006). With an emphasis on individual responsibility, this discursively (class and) 
gender-blind approach creates “an idealised female subject - one who will want to choose to have and raise children and will want to choose to be fulfilled, ultimately, through economic contribution” (MacLeavy 2007, 736).

The growth of higher education has enabled some women to obtain professional occupations and to command a more equal position in the labour market vis-a-vis men. As middle class women take on highly skilled occupations, political attention has focused on a potential 'care deficit' emerging in light of women's traditional caring role, culminating in women with lower levels of skills and training becoming overrepresented in these low-paid, part-time feminised 'caring' jobs (including domestic work, childcare and elder care). This reproduces gender inequalities in the labour market as women with lower educational attainment are disproportionately concentrated in less skilled occupations when compared with their male counterparts (Dyer et al 2011; ONS 2013).

The increased labour force participation of mothers, and emphasis within government policy on the responsibilities of citizen-workers, have challenged traditional understandings of 'good' mothering. The emphasis on everyday presence and childrearing amongst constructions of 'good' motherhood are largely absent from dominant social expectations of a ‘good’ father (Holloway, 1999; James 2011). Government promotion of mothers’ economic participation as a remedy to familial economic hardship and child poverty overlooks the value of mothers' unpaid work and their moral obligations towards their own family (Holloway 1999; James 2011; MacLeavy 2011a). The Working Tax Credits system and benefit sanctions coalesce to compel working class women to enter the labour market in the guise of decreasing child poverty, reducing social exclusion and fulfilling the duties of 'good' citizens (Vincent et 
al 2010), yet research points to structural and normative constraints limiting the employment opportunities of different women (McRae 2003; Wainwright et al. 2011).

What is striking about extant literature is that when the employment of mothers is considered, children are an absent present (cf. Ward et al 2007). The decisions mothers make in terms of their caring and earning responsibilities, and the way this is negotiated with partners tends to frame children as passive receivers of adult decisions, in need of childcare when parents go out to work (James 2011). Working class children are also framed as gaining from their parent's employment in government rhetoric, reducing social exclusion as well as benefitting from spending time in 'professional' childcare away from their parents (Smith et al 2011). In contrast, where parenting is judged positively (and thus conforms to idealised middle-class family norms), spending time away from parents is not seen to be in the best interests of children particularly when mothers' working hours are misaligned with children's schedules (Holloway and Pimlott-Wilson 2012).

Given the pervasive nature of employment in everyday life, there is an urgent need to give consideration to children's views of parental employment, acknowledging that children may experience and justify work in different ways to their parent(s), and the pay, conditions and the relative stability of a fathers' job have implications for the way children think about their mothers' paid work (Ridge 2009). This paper therefore explores parental employment from the perspective of children, focusing on their understanding of the gendered roles of their mothers and fathers. This paper serves to highlight how children justify employment within their parents' roles, exploring the influence of familial economic resources in their views. Firstly, the paper looks at how children perceive gendered parental roles in a context of relative security of employment within households headed by a parent(s) with professional or managerial 
jobs. Secondly, it examines the roles of mothers and fathers undertaking routine and manual jobs from the viewpoint of children. Finally the paper explores the lived experience of children in low-income families who experience low-paid employment. Incorporating children into these discussions is imperative, to understand the persistence and transformation of gender roles. In conclusion, the paper highlights the profound effects of labour market (in)security and (in)stability for whole families and the need for quality employment.

\section{Researching in/security}

This paper focuses on children's perceptions of employment in/security and unemployment by considering the lives of families residing in the deindustrialised coast of Cumbria, England. The area shares many features with other parts of northern England which have experienced a demise of the chemical, mining and steel industries to be only partially replaced by retail and service sector work, with stark disparities in levels of deprivation (Cumbria Intelligence Observatory 2012). In the towns of Workington and Whitehaven, “[d]eprivation is concentrated in large, mostly peripheral social housing estates. Employment is dominated by routine and manual work, and there are high levels of worklessness” (Blackman and Jennings-Peel 2007:3), with some of these wards falling within the $10 \%$ most deprived nationally. Concurrently, wards within the same borough are within the $10 \%$ least deprived in measures of those experiencing deprivation (Raw 2015). The County has been insulated against the global economic downturn relative to national trends due to the persistence of the maledominated nuclear and defence industries. However, Cumbria is highly vulnerable to cuts in public sector employment as part of the Coalition government's austerity drive, 
disproportionately affecting women (Cumbria Intelligence Observatory 2010; Pollard, 2013).

The research draws on a wider project exploring children's experiences of, and attitudes to, parental employment in different socio-economic contexts. Defining social class is always contentious and in this paper, class is used as a way to express the material and social status of families in the research. The paper follows Irwin and Elley (2011) who combine a wider community assessment with an individual measure in order to assign families to a class position. Families are described as 'middle class' if their children attend a school with an economically advantaged intake (a community measure) and their household's primary wage earner was employed in a managerial or professional occupation (an individual measure). In the middle class grouping, free school meal $\left(\mathrm{FSM}^{1}\right.$ ) rates are below 9\% (the national average in 2013 was 18.3\% (DfE 2013) and a school is defined as 'deprived' if over 30 per cent of children are eligible for FSM (DCSF 2009)). Families are described as 'working class' where their children attend a school that draws in more financially impoverished communities and their household's primary wage earner held a semi-/routine occupation (or had never worked/were long-term unemployed). In this group, the children attended schools where the FSM rate was mainly over $30 \%$.

Although the terms middle- and working-class are useful in this context as shorthand to describe the differences between the sub-groups, it is important to note the diversity of employment patterns within the sample (see Table I). The paper focuses on a subset of heterosexual two parent households to explore the ways in which children perceive paid labour and the gendered roles of their parent(s) in relation to employment. In both middle and working class households it was common for two-parent families to

\footnotetext{
${ }^{1}$ Free school meals are available to children whose parents are eligible for certain means-tested benefits.
} 
adopt a one-and-a-half earner model where the father is employed full-time and the mother takes part-time employment (Perrons et al 2006). However, the occupational type and hours of employment for each group were disparate. Over $60 \%$ of middle class mothers were employed during school hours only, compared to under $16 \%$ of employed working class mothers, who were more likely to work evenings (between 5pm and 9pm; 26\%) or nights (26\%). In a quarter of middle class households, fathers worked away during the week or had variable shift patterns as doctors, armed forces personnel and engineers compared to $4 \%$ of mothers who worked shifts in the locality as nurses. In working class households, the pattern was reversed as no fathers worked shifts or away from home during the week. A quarter of mothers worked shifts within a few miles' radius of the home, typically as carers and cleaners.

Table I: Employment in middle and working-class households

\begin{tabular}{lcc}
\hline & $\begin{array}{c}\text { Middle-class } \\
\text { households }\end{array}$ & $\begin{array}{c}\text { Working-class } \\
\text { households }\end{array}$ \\
\hline Two parent families & $\begin{array}{c}\text { \% of 2 parent } \\
\text { families }\end{array}$ & $\begin{array}{c}\text { \% of 2 parent } \\
\text { families }\end{array}$ \\
\hline 2 FT workers & 23.3 & 25.0 \\
\hline $\begin{array}{l}\text { 1 FT worker \& 1 PT } \\
\text { worker }\end{array}$ & 46.5 & 37.5 \\
\hline $\begin{array}{l}\text { 1 FT worker \& 1 } \\
\text { NPE }\end{array}$ & 25.6 & 16.7 \\
\hline $\begin{array}{l}\text { P PT worker \& 1 } \\
\text { NPE }\end{array}$ & $2.3^{*}$ & 8.3 \\
\hline 2 NPE & $2.3^{*}$ & 12.5 \\
\hline
\end{tabular}

Source: Authors interview data

Notes: FT= Full-time; PT=Part-time; NPE=Not in paid employment.

* These figures include households where parent(s) have retired from full-time professional occupations. 
The paper draws on interviews and activity-based methods with 67 children in Years 1 (aged 5-6 years old) and 4 (aged 8-9 years old). These methods include 'rainbows and clouds', developed as a means to depict positive and negative feelings about parental (non)employment, and Lego was utilised to explore the times and spaces of parental employment and domestic responsibilities using a hands-on activity (see self-citation). The interviews were all fully transcribed and to ensure anonymity, pseudonyms are used throughout.

\section{Employment security in middle class families}

In the professional and managerial households, parental employment is represented by children as a normative activity, epitomising a reliable and rational attitude to life (MacLeavy 2011b). This is particularly the case for fathers, as those without paid work were viewed as “[s]trange, because they’re silly... Because they don’t even work, they don’t know what they’re doing!...They wouldn’t be able to buy a tent, or a house” (Patrick, Year 1) and children “wouldn’t feel very comfortable with it” if their father did not work (Poppy, Year 4). Many respondents found it incomprehensible that no-one in a household would be in employment, and peers

"would think it was a bit strange [if neither parent was employed], because they normally have a mum and dad that would work... [If my parents didn’t work] I wouldn't know what to do, I wouldn't know where they would get their money from so I would like, question about where they would get their money from” (Robert, Year 4).

Some children are thus socialised to associate paid work with knowing one's place in society, having direction and being part of the 'normal' social order; a rhetoric that 
emanates from government policy (MacLeavy 2011a). Many of the children whose parents held managerial and professional occupations attended schools with very low free school meal rates, and discussed that they rarely encountered peers whose families relied on state benefits in their day-to-day lives (Harden et al 2013). Many thus talked about how "the only way you can get money is to go to work” (Harry, Year 4) and that those without paid work “just have to survive because they wouldn’t get any money would they?” (Eleanor, Year 4). The vast majority of children in this sub-grouping had no direct experience of labour market insecurity, and thus did not see it as affecting their lives.

When discussing their fathers' employment, none of the middle class children had concerns about job insecurity. This reflects both the relative stability of professional and managerial jobs in the occupational hierarchy and the insularity of the West Cumbria economy, alongside middle class parenting practices which strive to shield children from the realities of the workplace (self citation). Middle class children were uncomfortable considering unemployment for their father, with the result associated with being unable to purchase property: “I would have thought [if a friend’s dad was unemployed], they might not have that much, as much money as us...I would feel dead bad ‘coz they wouldn’t be able to like, afford a brand new house” (Zoe, Year 4). Homeownership in this context is an individualised consumption practice that is politically-charged and central to social responsibility and respectability (Smith 2008); a discourse inculcated in middle class children who equate unemployment with the inability to buy new or larger homes, and internalise feelings of embarrassment around peers affected by job loss. 
Children associated the employment of fathers with breadwinning; an indicator of social esteem, respectability and self-worth (MacLeavy 2011b). Those fathers who did not work were therefore cast in a negative light:

“it would probably be if he’s a bit thick [that a father wouldn’t have a job] .. because what I think is people that don't work didn’t do very well in school and they can’t get very good jobs” (Henry, Year 4).

Henry’s comment was typical for children living in middle class households who had no personal experience of labour market insecurity. Difficulties in gaining employment were individualised, with the person unable to find work cast as being mentally deficient, not engaging with the education system in appropriate ways and therefore not being rewarded with a highly-regarded position (Jeffrey 2010; Raco 2009). Structural inequalities in the education system and labour market do not come into Henry’s discussion but in situations when children have experienced insecurity for their own father in the past, their views are reworked.

Rachel recognised the difficulties her father faced in finding a job when she was younger. She emphasised the central role his human capital, individual attributes and level of effort played in securing paid work:

"my dad found it dead hard to find a job... So he did this really long passage [job application] about, that he was good at working, he had good skills and they let him in” (Year 4).

Within the sample, middle class children's representations of paid work (for men) coalesce with normative discourses within government policy which attribute difficulty in obtaining employment to the shortcomings of the individual who, with the appropriate social capital resources and personal effort, can overcome labour market 
insecurities (Hall et al 2013). This understanding of the stability of fathers'

employment for middle class children is significant in creating a backdrop for broader considerations of mothers' employment in two-parent households.

Conflicts between neoliberal notions of women as both workers and mothers (MacLeavy 2007) and institutional assumptions that the best environment for middle class children is the home - as they benefit from spending time with their competent mother (Holloway and Pimlott-Wilson 2012) - emerge from the accounts of children. In middle class households where mothers were employed, children appreciated the effect that their mothers' job had on the material conditions of their life but also the efforts she made to reconcile labour market, childcare and domestic demands (with varying levels of satisfaction). Although some children may have disliked their mother's working patterns, they still felt that an alternative scenario, where she did not engage in paid work, would be less desirable: “we wouldn’t get as much money as she has now... she buys lots and lots of toys as well and she wouldn't buy all of those” (Lucy, Year 1). Rather than talking about their mother going out to engage in paid work as an emotional 'loss' for them, many spoke about how a change in her employment status would mean a loss of material goods for them. Cornelia discussed how she preferred her mother to have a job for financial reasons:

"I like her going to work and earning money so she can buy us things and take us on trips and things. [If mum didn't work] it'd just be my dad working and he might get less money and not be able to buy as much things” (Cornelia, Year 4).

Cornelia appreciates the material goods which her mother's paid work brings, enabling her to "go out to places like the cinema and bowling". This is not to deny that there are cases where children dislike their mothers' employment pattern or appreciate that labour market engagement brings social benefits for their mum; yet the financial considerations 
of employment were key when discussing the gendered roles of parents. Jacob’s views were typical, suggesting that the consumption patterns of the family would be altered if his mum was unemployed, and thus he preferred his mum to

“work because without it you'd have no money to go on holidays and stuff like that ...we wouldn't go on holiday that much... We'd still have holidays but we'd have less ones” (Year 4).

Children's attitudes towards the money earned through maternal employment are situated within a context where families are relatively well off, acting as a supplement to the overall family income in order to sustain the standard of living children are accustomed to; justifications which are far removed from financial necessity (cf. MacLean et al 2010). Paid work is justified by children in relation to the monetary benefits and consumption patterns it sustains, renegotiating the mothering role to encompass labour market participation as a feature of 'good' mothering. However, children do recognise the benefits employment can also have for their mothers’ social interaction, self-esteem and skills (see also James 2008).

For the mothers employed in professional jobs, maternity leave was often followed by a reduction in working hours as in the case of Lara whose mother, an anaesthetist, worked reduced hours for a time as “it's quite hard to have a baby and also go to work... I think she should work because it gets money... it’s a bit easier (financially) as well” (Year 1). Lara believed that her mother did a disproportionate amount of domestic tasks:

“Daddy’s job’s sleep! That’s what he does in the house is sleep, sleep, sleep, sleep. My mummy's job is work, work, work, work, she takes the dogs out, she does the pigs, she does chickens, she looks after all the animals, she does fish, erm, she cleans all the mess up, she cooks breakfast then she cleans that up”. 
Lara understands her mother's domestic and caring duties as 'work' alongside the paid employment she also undertakes. Traditional gender norms persist as Lara’s mother retains primary responsibility for childcare and domestic tasks. However, Lara perceives her mother's role to also encompass economic provision in the form of a professional job. The one-and-a-half earner model frequently adopted in these middle class families (Table I) facilitates the reconciliation of production and social reproduction in families with a secure financial base (McDowell 2005; MacLeavy 2011a). Whilst this arrangement allows mothers economic independence, children perceive the uneven division of domestic and caring responsibilities between parents to place an unequal burden on mothers (James 2008).

Children of employed mothers were aware that paid work enables their mother to have some financial independence from their father, although the money was perceived to be directly benefitting her family (cf. Goode et al. 1998):

“The good things about my mum having a job is that she doesn't have to bother my dad for money...So when we go out in, onto outings with her and my mum, she can pay for us. She can pay for it herself out of her own money” (Robert, Year 4).

Robert justified his mother's employment in terms of her economic freedom, reducing the 'bother' of a dependent from his father. Middle class children equated the income from maternal employment with (what could be deemed) nonessential items, such as holidays, enrichment activities and days out rather than a central part of household survival (cf. Roberts 2013). Timothy's justification of parental employment in the context of material possessions is typical: 
[My parents are employed] "So we get more money and a big house ...if his

[friends'] mum and dad never worked, he wouldn't have no money for his extension would you and all your pool tables and your plasma screens?... You couldn’t do it without your mam and dad working” (Year 4).

Similarly, mothers enter the labour market "to get more money to look after us... We get to earn more money so therefore we get to have more fun, more holidays” (Alison, Year 4). Alison makes an explicit link between waged labour and care, as maternal employment in middle class, dual-earner families is discursively tied to caring through economic provision. These markers of middle class affluence, including larger houses, modern technology and enrichment activities are important to children who are accustomed to particular living standards which come from relatively stable and secure professional occupations (MacLean et al 2010). These capital-rich households are in a relatively privileged current position which acts as a safeguard against downward social mobility should change occur (Atkinson 2010). Mothers’ paid work was important for these children yet remained a supplement to their fathers' breadwinning wage in order to maintain middle class lifestyles.

\section{Labour market insecurity in working class families}

Labour market in/stability and in/security presented different challenges for children living in households headed by a parent with a routine manual or service occupation in comparison to their middle class counterparts. Many had experienced changes to their parents' employment status over the recent past, or knew someone close to their family who was unemployed. The male breadwinner ideology evident in middle class households was not as strongly articulated here when discussing their own family 
circumstances (although children still held gender normative ideas about appropriate jobs for men and women, for example). Job loss for fathers was seen as an unfortunate event which had broader implications for the rest of the family, but was a common feature of working class life where parents frequently moved from one low-paid, lowskilled job to another. Marie’s father experienced instability in his roofing job as “sometimes he goes to work, sometimes he doesn’t” (Year 4), with Kate preferring her father to work “but then the next day when my dad can’t got to work again, it’s just boring” (Year 4), as “I think it’s sad because because they [unemployed fathers] can’t get a job” (Thomas, Year 1). Employment for fathers is thus seen as preferable to unemployment, but discussions about the difficulties which men in low-paid occupations face when trying to gain work are recognised due to widespread instability in paid work; a significant deviation to Henry’s discussion of the individual failings of unemployed fathers (see previous section). The roles of fathers are thus negotiated in response to labour market issues, echoing McDowell’s (2003) research which highlights how working class young men negotiate their masculine identities in response to labour market changes. Abigail (Year 1) discussed her father's unemployment as a phase, an event which occurs with some frequency: "he used to [have a job] but he’s got retired [fired] but now he’s working for his, his friend Steve”. In describing her father's employment history, Abigail exhibits an in-depth understanding of his fluctuating employment status. Recurrent unemployment, low pay and insecurity are common features of the work trajectories of these fathers and others in the neighbourhood who held lower-skilled occupations.

Labour market insecurity and neoliberal policies designed to encourage labourmarket participation by reducing access to state benefits and instead promoting in-work benefits, undermine the moral choices of mothers who place great value on maternal 
presence (MacLeavy 2011a; Wainwright et al 2011). Yet in two-parent working class households, children indicated that the instability of the fathers' paid work necessitated maternal employment through times of financial hardship, in relation to delays in the processing of welfare payments. During her father's phase of unemployment Abigail's (Year 1) mother has been “cleaning at my grandas, that’s my mam’s dad and, my mam's dad's giving her money” and Thomas' (Year 1) mother “sometimes has to work in case my dad gets poorly" due to a lack of sickness pay. When her step-father suffered a work-related injury, Bethany felt it vital for her mother to accept paid work in order to ensure household survival (cf. Ridge 2009; Roberts 2013):

“she hasn’t got a very lot of money right now because that's, that's why she accepted the job so that she could get more money because with my step dad being out of work...She thought that if she gets the job then she could get more money and then she could like buy more food and everything... so that she could look after us even more better coz, she, you need money to look after yourself properly”.

In instances of male job loss, as Bethany’s family experienced, the Working Tax Credit system places a premium on female employment through strict conditions on welfare payments (MacLeavy 2011a). Financial necessity was frequently described as the motivating factor for mothers engaging in low-paid routine or manual occupations in order to bolster the family income, even though this may have jarred with mothers' desire to stay at home caring for her children.

One of the most common implications of fathers losing their jobs in working class households was described as food scarcity, whereas children in middle class households did not consider this as a consequence of unemployment. Engaging with the connection between food insecurity and unemployment is timely in light of growing 
evidence to suggest that families with children are at greatest risk of food poverty (Save the Children 2012). Gemma (Year 4) suggested that parents should work "because you'll be getting more money and you'll be able to get food and that more often”, drawing on her own experiences to suggest that without employment the family “wouldn’t be able to have enough money to buy food”. Bethany discussed how financial necessity compelled her mother into paid work, directly comparing past experience of unemployment and routine periods of food scarcity to the present, highlighting that "if she's working through the day then we can get more money to, so like we get more money, then we can be less hungry because we'll have more food” (Year 4). These children's accounts concur with social science research focusing on the narrative of adults which suggests that "[f]ood poverty hits the poorer sections of society much harder than the rest” (Goode 2012: 27). Fluctuating food security mirrors in/stability of employment as families move in and out of employment, and despite parental attempts to reduce impacts on children, the accounts presented here suggested children are highly aware of food scarcity.

Localised understandings of 'good' mothering (associated with 'being there' for children) are reworked in response to financial conditions, shaping and validating the decisions some mothers make in response to paternal job loss (Holloway 1999; Ward et al 2007; James 2008). This disjuncture between mothers’ desires to stay at home and the financial realities of the family resulted in some mothers expressing dissatisfaction with the labour market to their children, yet economic imperatives tie some mothers to the labour market. The next section explores how, for those children whose mother engages in paid work, the everyday realities of low-paid, insecure jobs are borne throughout the family. 


\section{Everyday realities of maternal low-paid work}

This section highlights some of the structural constraints acting upon working class mothers as they undertake paid employment from a disadvantaged labour market position. Children acknowledge the social benefits of employment for their mother but are also aware of the realities of low-paid work (self-citation). Government rhetoric positions employment as a panacea for poverty, encouraging working class mothers to engage in paid work (Smith et al 2011). This narrative overlooks the complex caring responsibilities mothers have (MacLeavy 2011b), their gendered moral rationalities and the changing nature of the labour market, accompanied by a growth in low-paid service work. Recent research has revealed that living with low-paid work, churning between low status occupations with little reward or security has an effect on poverty rates in families (Aldridge et al. 2012); yet the experiences of children living within these households receives less attention (Harden et al 2013; MacLean et al 2010; Ridge 2009). Working class parents accustomed their children to negotiate the disadvantages and opportunities of the local labour market (Gillies 2006; self-citation), yet a more nuanced understanding of the ways in which children understand the constraints of lowpaid work is vital to considerations of their everyday lives embedded within the family (Ridge 2009).

Children clearly appreciate the financial gains of their mother engaging in paid work, yet the reality of living with low-paid work means many mothers share a sense of powerlessness over their employment trajectories with their children. As localised understandings of motherhood associate presence in the home with care, this is renegotiated by some families in response to economic pressures. The nature of the jobs typically undertaken by mothers, particularly cleaning and care work, have a demand for early evening and night-time labour (accounting for 52\% of working class, 
employed mothers). This led to some households engaging in split-shift parenting (with the father working during the day, mother in the evenings) in order to resolve these conflicts. This arrangement may not be ideal for the mother or her children but is a pragmatic response to structural constraints (Warren 2004).

Family are often drawn upon to provide low-cost, trusted childcare but their availability is limited by their own working schedules such as in the case of Marie whose "mam works at nights and I have to go with my nana ...She just cleans banks" (Year 4) (cf. Ward et al 2007). Jonathan’s mother previously worked in “a chip shop and she was getting, it was the same hours like my dad and, they weren't working round each other” which caused childcare problems and thus his mother changed her job in order to reconcile it with caring responsibilities (Smith et al 2011). Inconsistencies in discourses surrounding the reconciliation of the good citizen-worker and good mother identities came across powerfully in Kate’s discussion of her mother's working hours. She disliked her mother's shift patterns yet Kate was aware that working atypical hours as a carer brought greater rewards:

she’s got to go to work at 8 o'clock, by 8 o'clock and if she doesn't, she doesn’t get paid...[She works] 8 o'clock in the morning until 10 o'clock at night, and when she’s all night, it's just the same except she works from 10 o'clock [pm] until 8 o’clock [am]. [I feel] Sad, because I don’t really want her to go to work and know she gets money, but I don't really want her to go to work because I can’t spend more time with her (Year 4).

Working class children were worried about the stress and difficulties of the lowpaid work which their parents engaged with; knowledge gained from discussions with parents about the realities of the workplace (self-citation), accustoming children to the challenges of the local labour market (Gillies 2006). Welfare reforms and government 
rhetoric combine to reproduce a myth that there are no 'bad' jobs, suggesting that career paths are open to those with the right attitude and commitment to work (MacLeavy 2011b). This discourse emanates from Henry’s scorn for unemployed parents (see section 'Employment security in middle class households'), yet the reality for those who live within an everyday cycle of poor work suggest that structural factors within the labour market and education system combine to limit choices. Tara appreciates the money from her mother's job but also feels that "she's got loads to do, it's always, it's not good... most of the time she’s got to work extra hard” (Year 4). She went on to suggest that her mother is trapped in her current job and "wants to get a better job ... she’s phoned up a couple of times but nothing's came back....[Now] she’s just getting on with her job”. Tara emphasised a sense of unhappiness, suggesting that her mother's lack of qualifications ensnared her in her current job, and without additional funds or alternative income, her mother could not afford to do additional training in order to increase her employment prospects (cf. Atkinson 2010). This contrasted with the employment trajectories of middle class mothers, who children described their ability to engage in employer-provided training or change jobs due to the relative economic security of the household.

Due to her father's disability and the nature of the sector in which she is employed, Sophie’s (Year 4) mum was unable to contemplate a change of career due to the reliance of the household on her wage:

I don’t really like her going to work because she has to go to work at half past 4 [pm] and she doesn't come home, until 3 o'clock in the morning....[her hours can’t change] because most of the [fast] food shops stay open dead late... my mam's job is more important because my dad doesn't work that many hours than my mam does... my mam does earn more money coz she works more hours... 
she did say that she would like to find another job but it would be hard for her changing jobs”.

Despite expressing discontent on both her own part and that of her mother, Sophie was resigned to her mother continuing in her current position for the foreseeable future due to the financial risks associated with a new, unfamiliar position. Children are aware of the realities of life within the employment system in which their parents are embedded (self-citation). Feelings of powerlessness and constraint are not confined to the individual worker but rather shape children's understandings of the labour market.

\section{Conclusions}

This paper furthers debate on the broad impacts of economic in/security through a case study focusing on children's perceptions of shifting gender roles in relation to parental employment. The empirics have traced how children perceive the relative saliency of male breadwinner ideology and the supplementary, yet still significant, role which maternal employment plays in professional and managerial households in order to sustain existing standards of living. In working class households, labour market insecurity had a destabilising effect on the gendered role of fathers from the viewpoint of children. Where service, manual and elementary occupations predominate, children believe that mothers' employment is central to 'caring' and the provision of basic needs, particularly in relation to food. In conclusion, the paper looks towards the wider lessons for gender, employment and economic in/security in the neoliberal state.

Firstly, the paper incorporates children's views of parents' gendered roles into extant literature. Insightful studies of gender inequalities in labour market 
opportunities and gendered responsibilities (James 2011; MacLeavy 2007) overlook the viewpoints of children, as they come to understand and experience mothers' and fathers' roles. Moreover, the neoliberal policy focus on parents as individual citizenworkers, and employment as a solution to child poverty, subsumes children's views within the broader family unit. Feminist geographers have drawn attention to the persistence of unequal gender relations in the home and workplace, alongside social class inequalities in employment opportunities between women (McDowell 2014). This paper contributes to this literature to illustrate how children view the gendered roles of parents in relation to production and social reproduction, and how these are bifurcated along class lines. Appreciating children’s views as distinct to, but also embedded within, the family is important beyond the sub-disciplinary borders of children's geographies. Examining how children’s lives are entwined with broader economic, social and political processes which affect both their own lives and those of their parents' highlights the imperative to listen to children in research examining women's reproductive work, capitalist production and the neoliberalisation of government policy.

Secondly, children’s accounts of their parents’ gendered roles draw attention to the inequalities between men and women, and between different social classes. Although evidence suggests that fathers are taking a more active role in childrearing (Kaufman 2013), this does not compensate for the unequal burden on mothers (James 2008). The one-and-a-half earner model frequently adopted in the middle class families culminated in increased labour market activity of mothers who continue to retain responsibility for domestic and caring duties (Dyer et al 2011). This arrangement allows mothers economic independence and social benefits associated with employment, yet adds to mothers' burden. In middle class families, children equate mothers' labour market participation and economic provision with 'care', undertaken 
alongside childrearing and domestic responsibilities. This has altered the normative alignment of motherhood with presence in the home to include financial provision, expanding the demands on mothers (Dyer et al 2011; James 2008). Despite the proliferation of maternal employment, the income of mothers in middle class households remains secondary due to the relative saliency of the male breadwinner ideology and inequalities in the caring responsibilities of partners. This raises questions about the extent of women's liberation and equality from the perspective of their children. At a time when fathering identities are undergoing change, children in middle class households still hold to traditional stereotypes which align fatherhood with breadwinning. This occurs in a context where fathers' jobs are relatively well-paid and the local economy is insulated from the global economic downturn due to the persistence of the male-dominated nuclear and defence industries (Cumbria Intelligence Observatory 2010).

Low-paid, low-skilled workers are disproportionately affected by labour market insecurity than those in professional occupations (Atkinson 2010). For working class children, this instability associated with precarious work acts to uncouple the relationship between fatherhood and employment. Children preferred their father to be in employment, yet the prevalence of job insecurity amongst the community results in a more amenable attitude towards financial provision for men. The economic factors which drive mothers into the labour market, from the perspective of their children in different socioeconomic groups, are distinct. In middle class households, children view their mother's employment as supplementary, bolstering stable incomes and advantaged lifestyles. In working class households, the proximity to economic necessity is greater and strict conditionality on welfare entitlements coerce mothers into low-paying, parttime occupations (MacLeavy 2011a), the effects of which impact upon children’s lives. 
Children's desires for their mothers to accept low-quality employment in order to avoid food scarcity draws attention to the fragility and instability which characterise the financial situations of whole families who are caught within a churning cycle of lowpaid work. It is timely to acknowledge the interplay between low-paid work and food insecurity from the viewpoint of children in light of growing evidence to suggest that families with children are at greatest risk of food poverty (Save the Children 2012).

Thirdly, the paper draws attention to how poor labour market positions affect not just individuals but rather whole families. The choice to participate (or not) with the labour market on an equal footing is a central element of feminist political theory. The viewpoints of children suggest that the integration of employment into mothers' caring role, and the quality of this employment, are significant for both women and their children. In a climate where government rhetoric stresses the role of the individual in success or failure in education and employment, inequalities continue to follow traditional forms of class and gender stratification (Atkinson 2013; McDowell 2014). The welfare system fails to recognise the unequal burdens of care which are borne by men and women, valorising paid work at the expense of household care work (MacLeavy 2011b). Policy discourse portrays those who do not work as dysfunctional and with poor work ethics (Aldridge et al. 2012), yet the occupations available to working class mothers compound a sense of powerlessness, rigidity and entrapment. Government policy needs to pay greater attention to the fragility and instability of the financial situations of many families who are caught within a churning cycle of lowpaid work, which in turn creates uncertainty for children. The stark reality that some children in the UK worry about the supply of food within the household if (or when) unemployment descends highlights the failings of a welfare system that is meant to support families in times of need. Children's accounts of low-paid work highlight the 
need to scrutinise the quality of employment that those in a disadvantaged labour market position feel compelled to take and the implications of this for all members of the family.

Children's perspectives of men's and women's gendered parental roles are clearly significant for their lived experiences in the here and now. Research exploring how this understanding of parents' gendered roles impacts upon the future expectations and aspirations of these children as they become young men and women is also vital. Analyses of gender inequality in society must engage with the diverse configurations of production and social reproduction which children from different social class backgrounds experience within the family, in order to appreciate how this impacts upon the ways in which young people think about their own family responsibilities and employment opportunities as they look towards the future.

\section{Acknowledgements}

This research was funded by the ESRC and a British Academy Postdoctoral Fellowship, and I gratefully acknowledge this support. I would also like to thank Sarah Holloway and three anonymous referees for their comments on an earlier draft of this paper.

\section{References}

Aldridge H, Kenway P, MacInnes T, Parekh A, 2012 Monitoring poverty and social exclusion 2012 (JRF, York)

Allen K, 2014, “UK services sector growth could bring forward interest rate rises” The Guardian, $6^{\text {th }}$ May 
Atkinson W, 2010, “The myth of the reflexive worker: class and work histories in neoliberal times” Work, Employment and Society 24 413-429

Atkinson W, 2013, "Class habitus and perception of the future: recession, employment insecurity and temporality” British Journal of Sociology 64 643-661

Blackman T, Jennings-Peel H 2007, The Whitehaven and Workington Neighbourhood Management Initiative Areas: a health impact assessment of housing, worklessness, children's services and primary care services (Durham School of Applied Social Sciences, Durham)

Cumbria Intelligence Observatory, 2010, Cumbria local economic assessment, November 2010 Download:

http://www.cumbriaobservatory.org.uk/elibrary/Content/Internet/536/675/4356/404581 1262.pdf

Cumbria Intelligence Observatory, 2012, Inequalities Available from http://www.cumbriaobservatory.org.uk/health/JSNA/Inequalities.asp Accessed $17 / 01 / 13$

Department for Children, Schools and Families, 2009, Deprivation and education: The evidence on pupils in England, Foundation Stage to Key Stage 4 Download: https://www.gov.uk/government/uploads/system/uploads/attachment_data/file/222172/ DCSF-RTP-09-01.pdf

Department for Education, 2013, Schools, pupils, and their characteristics, January 2013. SFR 21/2013 Download: https://www.gov.uk/government/uploads/system/uploads/attachment_data/file/207670/ Main_text-_SFR21_2013.pdf 
Dyer S, McDowell L, Batnitzky A, 2011, “Migrant work, precious work-life balance: what the experiences of migrant workers in the service sector in Greater London tell us about the adult worker model” Gender, Place and Culture 18 685-700

Gillies V, 2006, “Working class mothers and school life: exploring the role of emotional capital” Gender and Education 18 281-293

Goode J, Callender C, Lister R, 1998, Purse or wallet? Gender inequalities and income distribution within families on benefits (Policy Studies Institute, London)

Goode J, 2012, “Feeding the family when the wolf’s at the door: the impact of overindebtedness on contemporary foodways in low-income families in the UK” Food and Foodways 20 8-30

Hall S, Massey D and Rustin M, 2013, “After neoliberalism: analysing the present” Soundings 53 8-22

Harden J, Backett-Milburn K, MacLean A, Cunningham-Burley S, Jamieson L, 2013, "Home and away: constructing family and childhood in the context of working parenthood” Children’s Geographies 11 298-310

Holloway SL, 1999, “Mother or worker? The negotiation of motherhood and paid employment in two urban neighborhoods” Urban Geography 20 438-460

Holloway SL, Pimlott-Wilson H, 2012 “Neoliberalism, policy localisation and idealised subjects: a case study on educational restructuring in England” Transactions of the Institute of British Geographers 37.639-654

Irwin S and Elley S, 2011, “Concerted cultivation? Parenting values, education and class diversity” Sociology 45 480-495 
James L, 2008, “United by gender or divided by class? Women’s work orientations and labour market behaviour” Gender, Work and Organization 15 394-412

James A, 2011, “Work-life (im)‘balance’ and its consequences for everyday learning and innovation in the New Economy: evidence from the Irish IT sector” Gender, Place and Culture 18 655-684

Jeffrey C, 2010, “Geographies of children and youth I: eroding maps of life” Progress in Human Geography 39 496-505

Kaufman G, 2013, Superdads: how fathers balance work and family in the 21st Century (New York University Press, New York)

Lewis J, Campbell M, 2007, “Work/Family Balance Policies in the UK since 1997: A New Departure?” Journal of Social Policy 36 365-381

MacLean A, Harden J, Backett-Milburn K, 2010, “Financial trajectories: how parents and children discussed the impact of the recession” Twenty-first Century Society 5 159170

MacLeavy J, 2007, “Engendering New Labour’s workfarist regime: exploring the intersection of welfare state restructuring and labour market policies in the UK” Gender, Place and Culture 14 721-743

MacLeavy J, 2011a, “A ‘new politics’ of austerity, workfare and gender? The UK coalition government's welfare reform proposals” Cambridge Journal of Regions, Economic and Society 4 355-367 
MacLeavy J, 2011b, “Reconfiguring work and welfare in the UKs 'new economy': regulatory geographies of welfare-to-work at the local level” Gender, Place and Culture $18611-633$

McDowell L, 2005, “Love, money, and gender divisions of labour: some critical reflections on welfare-to-work policies in the UK” Journal of Economic Geography 5 $365-379$

McDowell, L, 2014, “Gender, work, employment and society: feminist reflections on continuity and change” Work, Employment and Society 28 825-837

McRae S, 2003 “Constraints and Choices in Mothers' Employment careers: a Consideration of Hakim's Preference Theory” The British Journal of Sociology 54 317338

Office for National Statistics, 2013, Full report - Women in the labour market Download: $\underline{\text { http://www.ons.gov.uk/ons/dcp171776_328352.pdf }}$

Perrons D, 2003 “The new economy and the work-life balance: conceptual explorations and a case study of new media” Gender, Work and Organisation 10 65-93

Perrons D, Fagan C, McDowell L, Ray K, Ward K, eds, 2006, Gender divisions and working time in the new economy: Changing patterns of work, care and public policy in Europe and North America (Edward Elgar, Cheltenham)

Pollard J, 2013, “Gendering capital: financial crisis, financialization and (an agenda for) economic geography” Progress in Human Geography 403-423

Raco M, 2009, “From expectations to aspirations: state modernisation, urban policy, and the existential politics of welfare in the UK” Political geography 28 436-444 
Raw R, 2015, Deprivation analysis: Allerdale. (Cumbria Intelligence Observatory, Carlisle) Download:

http://www.cumbriaobservatory.org.uk/elibrary/Content/Internet/536/675/1766/1775/42 07416030.pdf

Ridge T, 2009, Living with poverty: a review of the literature on children's and families' experiences of poverty, Research Report No 594 (Department for Work and Pensions) Download: http://dera.ioe.ac.uk/11015/1/rrep594.pdf

Roberts A, 2013, “Financing social reproduction: the gendered relations of debt and mortgage finance in twenty-first century America” New Political Economy 18 21-42

Save the Children, 2012, Child poverty in 2012: It shouldn't happen here (Save the Children, Manchester) Download:

http://www.savethechildren.org.uk/sites/default/files/documents/child_poverty_2012.pd $\underline{\mathrm{f}}$

Smith SJ, 2008, “Owner-occupation: at home with a hybrid of money and materials” Environment and Planning A 40 520-535

Smith F, Wainwright E, Buckingham S, Marandet E, 2011, “Women, work-life balance and quality of life: case studies from the United Kingdom and Republic of Ireland” Gender, Place and Culture 18 603-610

Stenning A, 2008, “For working class geographies” Antipode 40 9-14

Vincent C, Ball SJ, Braun A, 2010 "Between the estate and the state: struggling to be a 'good' mother” British Journal of Sociology of Education 31 123-138 
Wainwright E, Marandet E, Buckingham S, Smith F, 2011, “The training-to-work trajectory: pressures for and subversions to participation in the neoliberal learning market in the UK” Gender, Place and Culture 18 635-654

Ward K, Fagan C, McDowell L, Perrons D, Ray K, 2007, “Living and working in urban working class communities” Geoforum 38 312-325

Warren T, 2004, “Working part-time: achieving a successful ‘work-life’ balance?” The British Journal of Sociology 5599-122 